\begin{tabular}{|l|l|l||}
\hline \multicolumn{2}{|c|}{ PublisherInfo } \\
\hline \hline PublisherName & $:$ & BioMed Central \\
\hline \hline PublisherLocation & $:$ & London \\
\hline \hline PublisherImprintName & $:$ & BioMed Central \\
\hline \hline
\end{tabular}

\title{
Genes constantly evolve
}

\begin{tabular}{|l|l|l||}
\hline \multicolumn{2}{|c|}{ ArticleInfo } \\
\hline \hline ArticleID & $:$ & 4935 \\
\hline \hline ArticleDOI & $:$ & $10.1186 /$ gb-spotlight-20040407-01 \\
\hline \hline ArticleCitationID & $:$ & spotlight-20040407-01 \\
\hline \hline ArticleSequenceNumber & $:$ & 287 \\
\hline \hline ArticleCategory & $:$ & Research news \\
\hline ArticleFirstPage & $:$ & 1 \\
\hline \hline ArticleLastPage & $:$ & 3 \\
\hline \hline & & RegistrationDate : 2004-4-7 \\
\hline ArticleHistory & $:$ & OnlineDate \\
\hline \hline ArticleCopyright & $:$ & BioMed Central Ltd2004-4-7 \\
\hline \hline ArticleGrants & $:$ & \\
\hline \hline ArticleContext & $:$ & 130594411 \\
\hline \hline
\end{tabular}


A novel gene genesis mechanism suggests that the Drosophila genome is highly flexible and that even seemingly fixed genes are constantly evolving. This new research shows that genes are continuously created and altered by gene fission in a process of retroposed duplication followed by partial degeneration.

In the April 4 Nature Genetics, Wen Wang and colleagues in the Department of Ecology and Evolution at the University of Chicago looked for young genes - those that had originated within the last 1 or 2 million years - to observe the early stages of gene creation.

The team identified a group of genes with additional members and locations in members of the species Drosophila melanogaster subgroup that diverged less than a million years ago. Each subspecies has a parental gene sequence on one chromosome and different numbers of new copies on different chromosomes. The new copies are very young genes in evolutionary terms and so all the intermediate steps from the original parental sequence to the newest copies are visible. The gene family was named 'monkey-king' after the mythical Chinese character who could transform his hairs into offspring.

The authors observed that one single ancestral gene in the family - containing two functional domains - duplicated to produce an intronless copy. "The ancestral gene degenerates one of their domains in the 5 ' side, then the new gene duplicates, and that also degenerates and destroys the other domain," said Manyuan Long, senior author of the paper.

This also provides a mechanism to create new introns in the degenerate region of a previously intronless gene by creating new splice signals. "The intron can evolve from the exon if the exon becomes degenerated," Long said, suggesting that the coding portion of the genome is evolving.

The idea of gene duplication as a means of gene evolution has been around from some time, according to Wojciech Makalowski, associate professor in the Department of Biology at Pennsylvania State University. Here, the gene is duplicated without introns or regulatory regions and, in order to function, must land close to preexisting regulatory sequences.

In the classical model of segmental duplication, the whole gene is duplicated together with introns and regulatory elements, mutations in which may result in differential tissue expression. In addition, if the original gene had different splice variants and different exons were used in different tissues, exons could be lost after duplication. "In this paper, it would be yet another mechanism along this line: instead of degeneration of the single exon, now we have degeneration of the whole domain, so it really nicely complements the development of the theory," Makalowski, who was not involved in the study, said.

Berend Snel, from the Centre for Molecular and Biomolecular Informatics at the University of Nijmegen, said he did not know if this mechanism was likely to occur in prokaryotes, as the mechanisms involved - such as retrotransposition - are eukaryotic features. "The components replace the ancestral composite form, and this is typically more of a eukaryotic story of allowing for new functions," he said.

"When people think about evolution, they intuitively expect it to take some sort of direction towards more complexity - that is, multidomain proteins with more complex functions," said Snel, who was not 
involved in the study. "Sometimes, there's no such direction. That's why gene fission I think has been overlooked by some people."

Makalowski agreed. "Creating multidomain proteins with multidomain functions on the same protein to me is increasing complexity of the whole system - and now we are going back to the more simple system," he said.

\section{References}

1. Nature Genetics, [http://www.nature.com/ng/]

2. Manyuan Long, [http://pondside.uchicago.edu/ceb/faculty/long.html]

3. Wojciech Makalowski, [http://www.cse.psu.edu/gradbroc/faculty/makalowski.html]

4. Berend Snel, [http://www.cmbi.kun.nl/staff/BSnel.shtml]

This PDF file was created after publication. 